\title{
Industrial CHP excess heat efficient usage for cooling
}

\section{Priit Uuemaa ${ }^{1}$,}

\section{Haralds Vigants ${ }^{2}$,}

\section{Dagnija Blumberga ${ }^{2}$,}

Imre Drovtar ${ }^{3}$

${ }^{1}$ Department of Electrical

Power Engineering,

Tallinn University

of Technology,

Tallinn 19086, Estonia

E-mail:priit.uuemaa@student.ttu.ee

${ }^{2}$ Department of Electrical

Power Engineering,

Riga Technical University,

Riga LV-1658, Latvia

${ }^{3}$ Department of Electrical

Engineering, Tallinn

University of Technology,

Tallinn 19086, Estonia
This study investigates the possibilities how to utilize the combined heat and power plant (CHP) excess heat in the industry during the hot periods of time when the heat demand is limited. In order to maximize the CHP electricity production the efficient heat load has to be increased. The goal of this article is to present the solution for the industrial CHP excess heat utilization for the local cooling. The study introduces the method and model of how to evaluate the industrial CHP plant potential and economical benefit for the production of local cooling from the excess heat.

Key words: combined cooling, heat and power plant, energy efficiency, HVAC systems, industrial processes

\section{INTRODUCTION}

CHP plants are widely used in the areas where there is a heat demand. They can be categorized into two categories depending on the nature of the heat consumer. Firstly, the district heating (DH) CHP plants which use the DH network to transfer the heat to the residential area which is either a city or a local settlement. Secondly, the industrial CHP, which produces the heat to the on-site industry or for the group of industries nearby. Depending on the industry production profile, the heat consumption is usually lower in the summertime whereas the cooling demand is 
the biggest. Therefore this makes the production of local cooling from the excess heat an efficient solution to improve the economical performance of the entire facility.

The maximum heat production is limited in the summertime due to the decreased heat demand. Since the industrial CHP plants are mainly working with back pressure turbines, in order to maximize the thermodynamical efficiency, the electricity production will decrease accordingly during the periods of lower heat demand. Therefore, finding solutions to increase the heat load is a key factor for maximizing the CHP electricity production and hence the economical performance of the plant.

Technically a CHP plant can also operate in condensing mode during the summer period if the plant has sufficient auxiliary cooling devices. However, the relatively low electrical efficiency and low electricity market price do not cover the variable cost of the fuel. Utilizing the excess heat for producing local cooling enables the CHP to increase its electrical output. In an ideal case it could run as a base load plant which produces electricity on full load all year round maximizing the operational profit. Primarily, the additional income comes from increased electricity production. Some income would also come from savings on cooling costs that otherwise would be done with solely electricity driven chillers.

Contribution of this study is to investigate the local absorption chiller profitability in wood industry under open electricity market conditions. In the 2 nd section the previous research is introduced, in the 3 rd section the CCHP operation in the open electricity market conditions is introduced, 4th section outlines the possibilities in the wood industry and a specific example case study is performed. In the 5th section the study is concluded.

\section{PREVIOUS RESEARCH ON HEAT BASED COOLING}

Industrial three generation means production of electricity, heat and cooling in a combined cooling, heating and power (CCHP) plant. The authors of [1-3] have optimized the CCHP operation in order to minimize the operational cost and have concluded that the optimized CCHP operation has better economical results than the non-optimized system. They have simulated a consumer with the cooling demand and shown that the cooling system which is driven by the recovered heat has operational savings and allows the CHP to increase its electrical output.

Heat based cooling is often not used due to the insufficient knowledge about its possibilities and also the high investment cost of the technology. Normally the industrial cooling demand is covered with electricity driven chillers [4]. Authors of [5] have studied the adsorption systems in different applications. They have introduced the development of relevant materials, technologies and projects. As they have concluded, the adsorption chiller technology has a great potential for converting the waste heat to the useful cooling. However, the most commonly available technology for the heat driven cooling is an absorption chiller [5]. The absorption chiller enables to recover the heat and produce cold water. Authors of [7] propose to use the absorption cooling in the summertime from waste heat in order to save costs. Authors of [8] have developed a new optimization method which optimizes the cost, emissions and social impact through using the absorption systems.

Cooling possibilities in the industry by using locally produced heat have been investigated intensively by authors of [9-11]. They all line out that the industrial absorption chiller has to be studied case by case, because it does not necessarily mean lower overall cost compared to the stand-alone cold water production. They have shown it is worth to exploit the saving opportunities through heat based cooling. However, their studies are mainly focused on lowering the cost and primary energy consumption rather than maximizing the profit. Authors of [12-14] have illustrated that it is profitable in commercial buildings large enough to use a heat based central cooling unit. They prove that the waste heat based cooling is allowing the system to be operating in a more profitable manner than the system with the electricity based cooling. They also point out the importance of the size effect of the cooling system. This means that there has to be a minimum critical cooling load which makes it worth to use the central cooling rather than local chillers. In another studies, the authors of [15-17] have in- 
troduced different optimization strategies based on the load distribution between heat and cooling energy production. The main idea of the authors [18-19] has been to investigate the environmental impacts and cost effectiveness of CCHP systems.

The previous research, as described above, has introduced different cooling technologies and proves that the absorption based cooling is the most suitable waste heat based cooling technology. Therefore the absorption chiller is chosen for the production of industrial cooling in this study. The previous research has also shown the positive effect on the cost, emissions and fuel savings of the excess heat utilization in the CCHP systems. The focus of this study is to exploit even further and maximize the electricity production by converting the existing CHP into the CCHP plant. This conversion helps to improve the economical performance of the entire industrial facility and hence maximize the profit.

\section{CCHP OPERATION IN THE OPEN ELECTRICITY MARKET CONDITIONS}

Majority of the CHP variable cost is usually the fuel cost. Therefore the CHP is operated based on the cost of the fuel. In normal operation the power plant is expected to run even in a condensation mode if the electricity production income covers the variable cost of the plant [20]. Otherwise it is more profitable not to run the plant.

The marginal cost of the CHP is the cost to produce one extra MWh of electricity. In this study the marginal cost definition is rather equal to the short-term marginal cost. When changing the power plant load from the partial load to the full load, then there is no other significant marginal cost than the fuel cost. The CHP is expected to increase the electrical output as long as the plant marginal cost is covered. Therefore traditionally the criterion for operating the power plant is written in Equation 1:

$$
W_{e} \cdot P_{e}>W_{f} \cdot P_{\rho}
$$

where $W_{e}$ is the production of electricity in $\mathrm{MWh}$, $P_{e}$ is the electricity spot market hourly price in $€ /$ $\mathrm{MWh}, W_{f}$ is the consumption of fuel in MWh and $P_{f}$ is the price of the fuel in $€ / \mathrm{MWh}$. Therefore in any case where income exceeds the variable cost of the production, the plant is expected to produce electricity.

CHP produces two forms of commercially usable energy - electricity and heat. In this study the third sales article is also introduced - cold production. Usually the traditional biomass fired power plants have quite low electricity share in the total produced energy [21]. This, however, is compensated with the significantly high total efficiency on conversion of the primary fuels to the useful energy [22]. Therefore utilizing the heat in a commercially rational way distinguishes the CHP from a conventional heat condensing power plant. It allows the producer to be more competitive on the electricity market as well as save the primary fuels in the energy sector. In this aspect the existence of the heat load has the critical influence on the CHP operation. Introducing the cold production enables the CHP to increase the heat production and therefore also produce additional electricity to the market. The CHP technical thermodynamical efficiency can be described as follows in Equation 2:

$$
\eta_{n}=\frac{W_{e}+W_{h}}{W_{f}}=\eta_{e}+\eta_{h}
$$

where $W_{e}$ is the production of electricity in MWh, $W_{h}$ is the production of heat in MWh, $\eta_{n}$ is the nominal total efficiency of the plant, $\eta_{e}$ is the electrical efficiency of the plant and $\eta_{h}$ is the heat efficiency of the plant. Usually the biomass CHP-s total efficiency is in the range of 0.85-0.9.

The heat production $W_{h}$ can be divided between the heat consumer and the cooling consumer as follows in Equation 3:

$$
W_{h}^{H}=W_{h}^{H}+W_{h}^{C},
$$

where $W_{h}^{H}$ is the heat that is used for heating and $W_{h}^{C}$ is the heat that is used for cooling. Cooling heat is the sum of different types of cooling applications, in this study it is air conditioners and process cooling as shown in Equation 4:

$$
W_{h}^{C}=\frac{\left(W_{A C}+W_{P C}\right)}{\eta_{A B S}},
$$

where $W_{A C}$ is the cooling load of air conditioners in $\mathrm{MWh}, W_{P C}$ is the cooling load of process cooling in MWh and $\eta_{A B S}$ is the efficiency of the absorption chiller. 
The main principal of the CHP plant is that usually it runs according to the heat load due to the reason that in the condensation mode it is not competitive enough on the electricity market. The ability to sell the produced heat to the $\mathrm{DH}$ network or to the industrial customer makes the CHP plant electricity price much more competitive. When the CHP plant can sell the produced heat, then this income will be added on top of the electricity income. This in return allows the CHP plant electricity price to be lower than the average market price.

Heat market enables the CHP plant to exploit the total efficiency for its benefit. However, maximizing the total efficiency decreases the electricity share in the total energy production mix and this share is lower than in conventional condensing power plants. Therefore, with the same primary fuel the condensing power plant electricity price is lower and it can sell its electricity on the spot market whereas the CHP electricity offer is not accepted due to too high price. The price formation in the electricity spot market depends on numerous aspects, but, as explained above, the average electricity spot price level is too low for the biomass CHP. In the traditional condensing power plant the electricity output is maximized sacrificing the efficiency of total primary energy usage. In order to run the CHP plant electrical output even more than the available heat load would allow then criterion 5 below, which is in accordance with Equation 1, has to be fulfilled:

$$
W_{e}^{\text {extra }} \cdot P_{e}+W_{e}^{\text {extra }} \cdot P_{h}>W_{e}^{\text {extra }} \cdot P_{\rho}
$$

where $W_{e}^{\text {extra }}$ is the additional electricity produced due to the increased heat load in $\mathrm{MWh}_{\mathrm{e}}$, $W_{h}^{\text {extra }}$ is the additional artificial heat load in $\mathrm{MWh}_{\mathrm{th}}, P_{h}$ is the price of the heat in $€ / \mathrm{MWh}, W_{f}^{\text {extra }}$ is the required additional fuel for the bigger load point in MWh. The price of the additionally produced heat can be either negative or positive depending if the additional heat is commercially needed or it is just cooled down. If it is cooled down (condensed), then there is a negative cost for the condensing operation itself, i. e. electricity cost of the fans, operational condensing costs. If it is commercially needed for the cooling then there is a positive price for that additional heat. In this study the available cooling demand is covered by the additional heat which is produced in the CHP. When converting some of the CHP heat production to commercially needed cold water, the plant becomes a CCHP.

The price of heat, which is consumed for commercially needed cooling, can only be determined by the alternative cost compared to costs occurring with traditional chillers or air conditioners (ACs). Usually there is no market for cooling and hence no market price for cooling because there is no district cooling networks. The cooling energy price can only be calculated by the savings it gives to the facility when it switches over from the electricity driven local cooling to the central excess heat based cooling. Therefore the excess heat income can be written in Equation 6 as follows:

$$
W_{h}^{C} \cdot P_{h}^{C}=S_{A C}+S_{P C^{\prime}}
$$

where $P_{h}^{C}$ is the price of the heat which is used for the absorption chiller in $€ / \mathrm{MWh}, S_{A C}$ is the operational cost savings with the absorption chiller compared to reference case electricity based air conditioning in $€, S_{P C}$ is the operational cost savings with the absorption chiller compared to reference case electricity based process cooling (PC) in $€$.

In order to define the savings, then two different scenarios have to be compared. What is the operational cost of the reference case AC and PC when this cooling is produced separately by the electricity driven applications and what is the operational cost of the absorption chiller based cooling? The savings can be calculated according to Equations 7 and 8:

$$
\begin{aligned}
& S_{A C}=\left(C_{e}^{A C}-C_{e}^{A B S}\right) \cdot\left(P_{e}+P_{T}\right), \\
& S_{P C}=\left(C_{e}^{P C}-C_{e}^{A B S}\right) \cdot\left(P_{e}+P_{T}\right),
\end{aligned}
$$

where $C_{e}^{A C}$ is the reference case AC's electricity consumption in $\mathrm{MWh}, \mathrm{C}_{e}^{A B S}$ is the absorption chiller based system electricity consumption in $\mathrm{MWh}, C_{e}^{P C}$ is the reference case PC electricity consumption in $\mathrm{MWh}, P_{T}$ is the remaining marginal electricity consumption cost in $€ / M W h$.

Since the consumer has various price components on the purchased electricity, then these components have to be taken into account. They 
are separated from the electricity spot price due to the reason that the spot price is given for each hour separately throughout the year, but the remaining components are most likely fixed by the regulation. However, these components vary significantly through different countries and locations therefore they cannot be clearly written in the equations. It rather depends on the location specific regulation. For example, the MWh which is purchased through the public network includes the retail cost, balancing cost, system operator transfer cost, distribution operator tariff, mandatory government taxes, direct costs. In most of the places these costs can be even higher than the electrical energy itself. However, if the facility consumes the electrical energy which is produced on the site directly, then only some of these components can be added, like taxes because the electricity is not purchased through the public network. Therefore in order to determine the facility electrical energy savings, the location specific marginal electricity cost $P_{T}$ has to be taken into account case by case.

It has to be outlined that heat based cooling which is based on the absorption chiller has a size based cost-effect. It can be assumed that a small cooling capacity can be fulfilled much more efficiently locally with the electrical AC, rather than provide cold water from distance which requires additional water pumps and operational energy and hence higher cost. If all the extra heat $W_{h}^{\text {extra }}$ is consumed by the absorption chiller, then Equation 3 could be rather written as follows in Equation 9:

$$
W_{e}^{\text {extra }} \cdot P_{e}+S_{A C}+S_{P C}>W_{e}^{\text {extra }} \cdot P_{f}
$$

This means that the CHP plant will run on market conditions with the higher electrical load if the savings from the absorption chiller usage together with the additional electricity income are bigger than the cost of the extra fuel. In biomass based power plants there are usually in the European Union always some subsidies involved [23]. Absorption chiller based cooling enables the CHP plant to increase electricity production and hence receive the additional subsidy income on top of the electricity price as shown in Equation 10:

$$
\begin{aligned}
& W_{e}^{\text {extra }} \cdot\left(P_{e}+S_{R}\right)+S_{A C}+S_{P C}> \\
& >W_{f}^{\text {extra }} \cdot P_{f}
\end{aligned}
$$

where $S_{R}$ is the case by case specific subsidy in $€ /$ $\mathrm{MWh}_{\mathrm{e}}$ received by the producer according to the regulation. Since the feed-in tariff based subsidy does not require the producer to participate on the electricity market then this type of subsidy is not taken into account in this research. In Equation 10 the so called feed-in premium is considered.

There are no restrictions to run the CHP plant on a condensing mode, but in that case the plant has to manage with market conditions. This, however, is not possible in Estonia or other Baltic States where the fuel cost is higher than income from electricity [24-26] as per Equation 1. It should be noted that the profitability of exploiting heat based cooling opportunities is strongly affected by the local energy policies and therefore is a subject to the energy policy changes.

Usually the standard biomass fired CHP plant total efficiency $\eta_{n}$ is higher [22] than normally required $\eta_{R}$ [23] by the regulation in order to receive the subsidy. Therefore the plant can operate in the partially condensing mode at certain higher range of efficiency as long as the minimum required total efficiency is maintained, criterion 11:

$$
\frac{W_{e}+W_{e}^{R}+W_{h}}{W_{f}} \geq \eta_{R}
$$

where $W_{e}^{R}$ is the additional electricity that can be produced without losing the subsidy and $\eta_{R}$ is the minimum required total efficiency for receiving the subsidy. In that case the $\eta_{n}>\eta_{R}$ additional regulatory dependent electricity production can be written as follows in Equation 12:

$$
\begin{aligned}
& \left(W_{e}^{\text {extra }}+W_{e}^{R}\right) \cdot\left(P_{e}+S_{R}\right)+ \\
& +S_{A C}+S_{P C}>W_{f}^{\text {extra }} \cdot P_{f}
\end{aligned}
$$

The optimization algorithm for the total CCHP plant operational profit maximization can be written in Equation 13 as follows:

$$
\max \sum_{t=1}^{n}\left(W_{e t} \cdot\left(P_{e t}+S_{R t}\right)+W_{h t}^{H} \cdot P_{h t}+W_{h t}^{C} \cdot P_{h t}^{C}-W_{f t} \cdot P_{f t}\right)
$$

where $t$ is the time period of one hour. 


\section{POSSIBILITIES IN THE WOOD INDUSTRY CHP}

Key figures describing the facility under investigation

This section uses the method developed in the previous section to investigate excess heat utilization for cooling purposes and find the economical feasibility of the cooling process. The wood industry located in Estonia is under investigation. The industry main production activity is wood processing. Therefore the facility needs heat for the drying process and cooling air to cool down the final product. Additionally, cooling is also needed for the utility and office rooms, which is at the moment done by local air conditioners. The industry also operates the on-site CHP plant which produces the required heat for the drying process. The key parameters of the industry under investigation are summarized in Table 1.

However, since the drying process requires less heat in the summertime due to higher ambient air temperature the excess heat is left over. Figure 1 illustrates the actual heat production profile for the industrial CHP under investigation. The studied CHP plant is built with a backpressure turbine making it impossible to adjust the heat production without losing the electrical output. Therefore the decrease in the heat output also decreases the electricity output. At the same time Fig. 1 also includes the modeling results of the possible cooling capacity that could be added on top of the overall heat load. The remaining peaks which still have excess heat available can be simply cooled down with the dry coolers which are installed in the CHP plant while still maintaining the required minimum $75 \%$ total technical efficiency.

During the times of higher ambient temperature the drying process uses less heat. On the other hand, higher ambient air temperature requires more cooling energy to cool down the industrial product which is more energy intensive when the temperature rises. Therefore this makes the cooling demand an ideal substitute for the heat consumption decrease. In Fig. 1 there are also some normal operation dips which are either caused by planned or unexpected maintenances.

Table 1. Key figures of the industrial facility under investigation

\begin{tabular}{|c|c|c|c|c|}
\hline Input data & Variable & Value & Unit & Source \\
\hline $\begin{array}{c}\text { CHP electrical output } \\
\text { capacity }\end{array}$ & $W_{e}$ & 6.50 & $\mathrm{MW}_{\mathrm{e}}$ & Case study industry \\
\hline CHP heat output capacity & $W_{h}$ & 18.00 & $\mathrm{MW}_{\text {th }}$ & Case study industry \\
\hline CHP total efficiency & $\eta_{n}$ & 0.89 & & Case study industry \\
\hline Fuel price & $P_{f}$ & 12 & $€ / M W h$ & {$[24-25]$} \\
\hline Subsidy, feed in premium & & 53.7 & $€ / \mathrm{MWh}_{\mathrm{e}}$ & {$[27]$} \\
\hline Price (savings) for cooling & $S_{C}$ & 0.00 & $€ / \mathrm{MWh}$ & Case study industry \\
\hline Process cooling airflow & & 90000 & $\mathrm{~m}^{3} / \mathrm{h}$ & Case study industry \\
\hline $\begin{array}{l}\text { Process cooling } \\
\text { temperature }\end{array}$ & & 5 & ${ }^{\circ} \mathrm{C}$ & Case study industry \\
\hline Heat exchanger efficiency & & 0.85 & & Case study industry \\
\hline $\begin{array}{l}\text { Air conditioner } \\
\text { (AC) capacity }\end{array}$ & & 0.334 & $\mathrm{MW}_{\text {th }}$ & Case study industry \\
\hline $\begin{array}{c}\text { AC load factor, } \\
t>10^{\circ} \mathrm{C}\end{array}$ & & 1 & & Case study industry \\
\hline $\begin{array}{l}\text { AC load factor, } \\
-10^{\circ} \mathrm{C}<t<10^{\circ} \mathrm{C} \\
\end{array}$ & & 0.75 & & Case study industry \\
\hline $\begin{array}{c}\text { AC load factor, } \\
t<-10^{\circ} \mathrm{C}\end{array}$ & & 0 & & Case study industry \\
\hline Absorption chiller efficiency & $\eta_{A B S}$ & 0.75 & & Case study industry \\
\hline$t^{\circ}$ below full heat load required & $t_{\max }$ & 10.00 & ${ }^{\circ} \mathrm{C}$ & Case study industry \\
\hline $\begin{array}{l}\text { Investment cost of } \\
\text { the absorption chiller }\end{array}$ & & 170000 & $€ / \mathrm{MW}_{\text {th }}$ & Case study industry \\
\hline
\end{tabular}


Due to the reason the modeling uses the case study facility actual historical data, these dips are not taken out from the profile and are not meant to be filled with cooling load either. These dips are rather shown as a part of the modeling results.

As it is presented in Fig. 1, the majority of heat is used by the heat consumer which is the dryer unit and heat valleys are covered by the cooling demand in the summer period. The combined heat load makes the production profile much more close to the base load plant profile. This in return allows more stable operation. The actual case study facility excess heat volume relation to the ambient air temperature is shown on Fig. 2. As explained above, in order to maximize the electricity production dry coolers are necessary to cover the reaming excess heat peaks which cannot be covered by cooling load.

The excess heat deviation in the same ambient air temperature range is caused by different operational influences. For example, if the heat consumer has more pollution like dust in the system, the heat transfer is poorer and hence more excess heat is left over. Therefore auxiliary cooling devices would also improve the reliability of the system.

\section{Wood industry case study}

In the Nord Pool Spot market Estonia area small scale CHP plants cannot run on a condensing mode in the market conditions because the fuel cost exceeds the electricity market price. According to the Estonian statistical database and state forest sales prices, the average biomass fuel price was $12 € / M W h$ [24-25] in 2012. In the same year, the average electricity market price was $39.2 € /$ MWh [26]. If the CHP total technical efficiency $\eta_{n}$ is $89 \%$, then the fuel consumption on full load is $27.5 \mathrm{MW}$. According to Equation 2 this makes the electrical efficiency $\eta_{e} 24 \%$. This means that $24 \%$ of the primary energy are converted to the secondary energy, in this case electricity. With this electrical efficiency, the power plant short term marginal cost would have been $50.0 € /$ $\mathrm{MWh}_{\mathrm{e}}$ which significantly exceeds the electricity price. The traditional biomass fired small CHP plant would not be operating in these conditions.

Currently, the industry has $0.3 \mathrm{MW}_{\text {th }}$ of cooling load for utility rooms and office which is at the moment cooled with electrical air conditioners. The wood processing also requires $0.8 \mathrm{MW}_{\text {th }}$ of cooling load to cool down the product. At the moment it is cooled down with

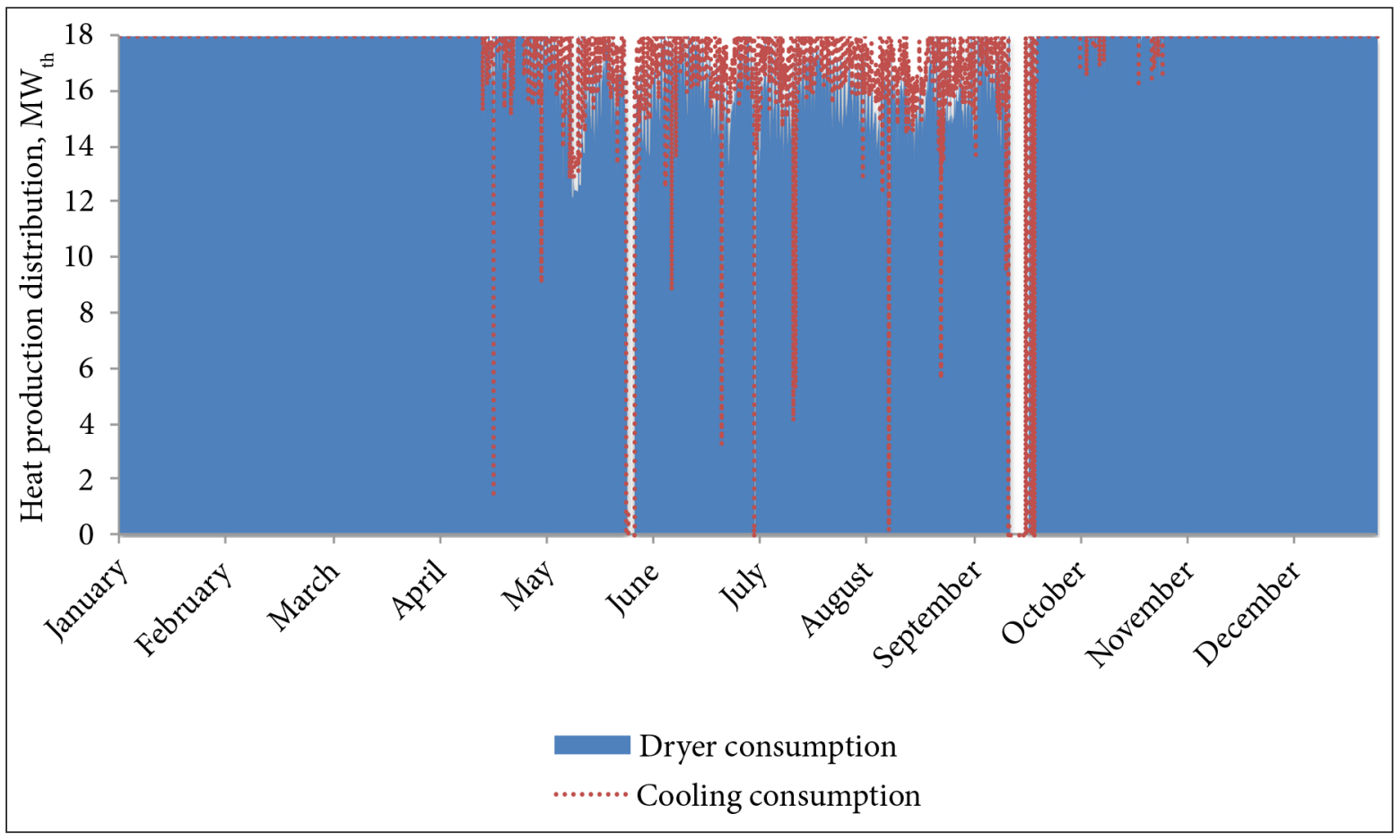

Fig. 1. Case study facility actual heat consumption profile where the added cooling load can help to even out the heat consumption in the summer period 


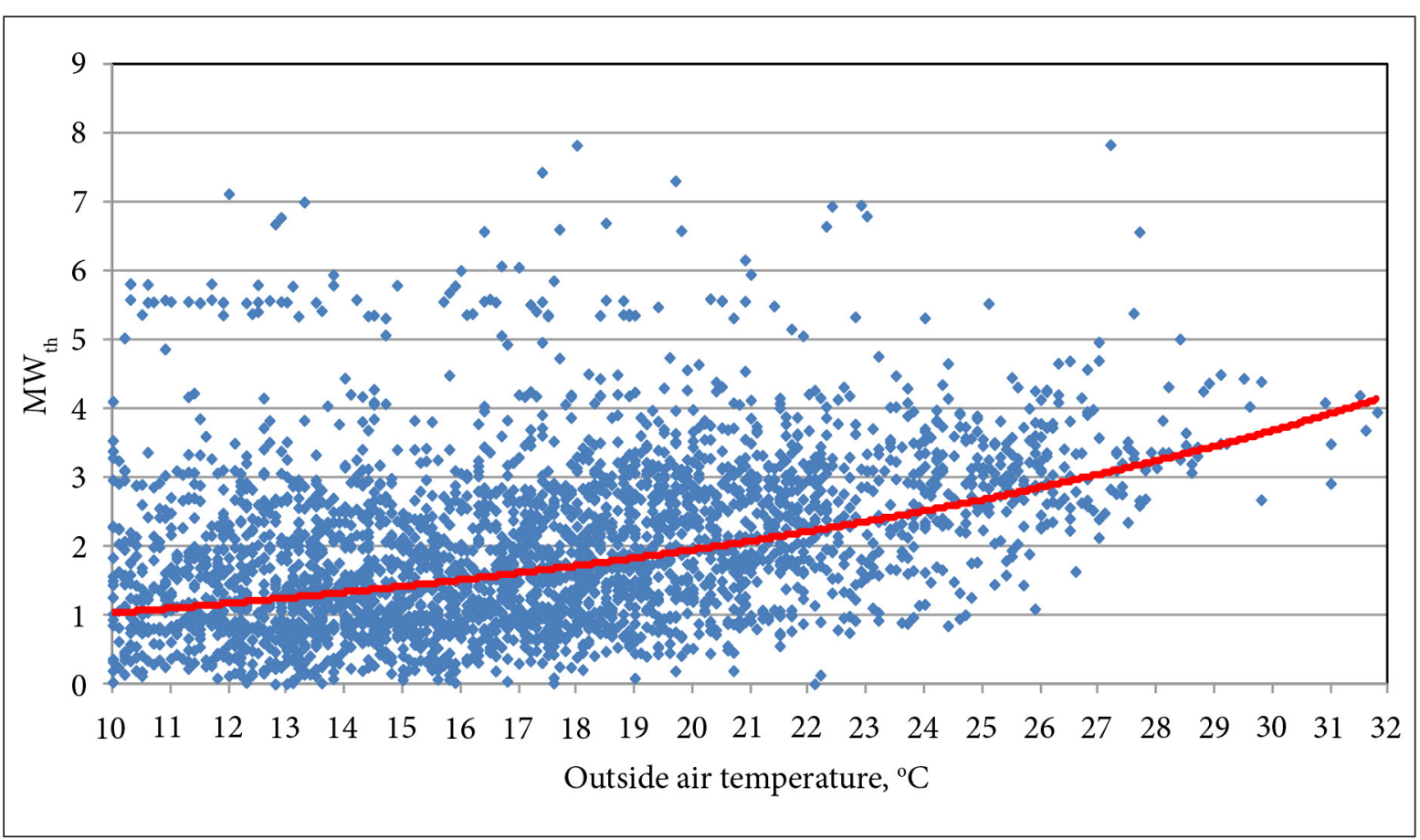

Fig. 2. Case study facility existing excess heat pro-

duction relation to the ambient air temperature

outside air and is not using the chillers. However, if a heat exchanger would be used, the electricity consumption of the fan would be lower. The company also loses some of the product quality due to the lack of cooling capacity during the summer period. In total, the existing cooling demand is $1.1 \mathrm{MW}_{\mathrm{th}}$. However, in order to convert this cooling capacity from the heat network and taking into account the conversion factors, the total cooling load in the heat network would be 1.7 $\mathrm{MW}_{\text {th }}$ as shown in Table 2. As it is presented in Fig. 2, the excess heat production can be up to $7.8 \mathrm{MW}_{\text {th }}$ which exceeds the cooling demand. Therefore, the remaining 6.1 $\mathrm{MW}_{\text {th }}$ excess heat has to be cooled down by the dry coolers shown in Fig. 3 in order to maximize the electricity production.

The industry under investigation operates the CHP plant with the output power of $6.5 \mathrm{MW}_{\mathrm{e}}$ and $18 \mathrm{MW}_{\text {th }}$ throughout the whole year, stopping only for annual maintenance. The heat is used currently $100 \%$ in the drying process of the same company. However, in the summer time the heat demand for the drying process decreases due to higher ambient air temperature. At the same time, the cooling capacity rises for the electricity rooms cooling and for the process cooling. The proposed system for the developed industrial three generation is shown in Fig. 3.

In Fig. 3. the proposed process diagram is shown for the case study facility. Instead of using all the heat in the dryer and being dependent on the dryer heat consumption, the CHP can be run also using the excess heat in the cooling demand. For the cooling demand the absorption chiller is needed in the conversion of the heat to the cold water. In case the cooling load is not sufficient enough to maximize the electricity production, the dry coolers will start to work to cool down the remaining portion of the heat and maximize the electricity production and hence the profit.

\section{RESULTS}

Case study industry calculation results for the cooling energy production are given in Table 2. As it is shown, the payback time for the absorption chiller is less than 6 years. In addition to that, there is an environmental saving through less used primary fuels.

The above case study calculations are done with the assumption that no heat is wasted or condensed. The payback time for the absorption chiller is calculated on the additional useful heat load that 


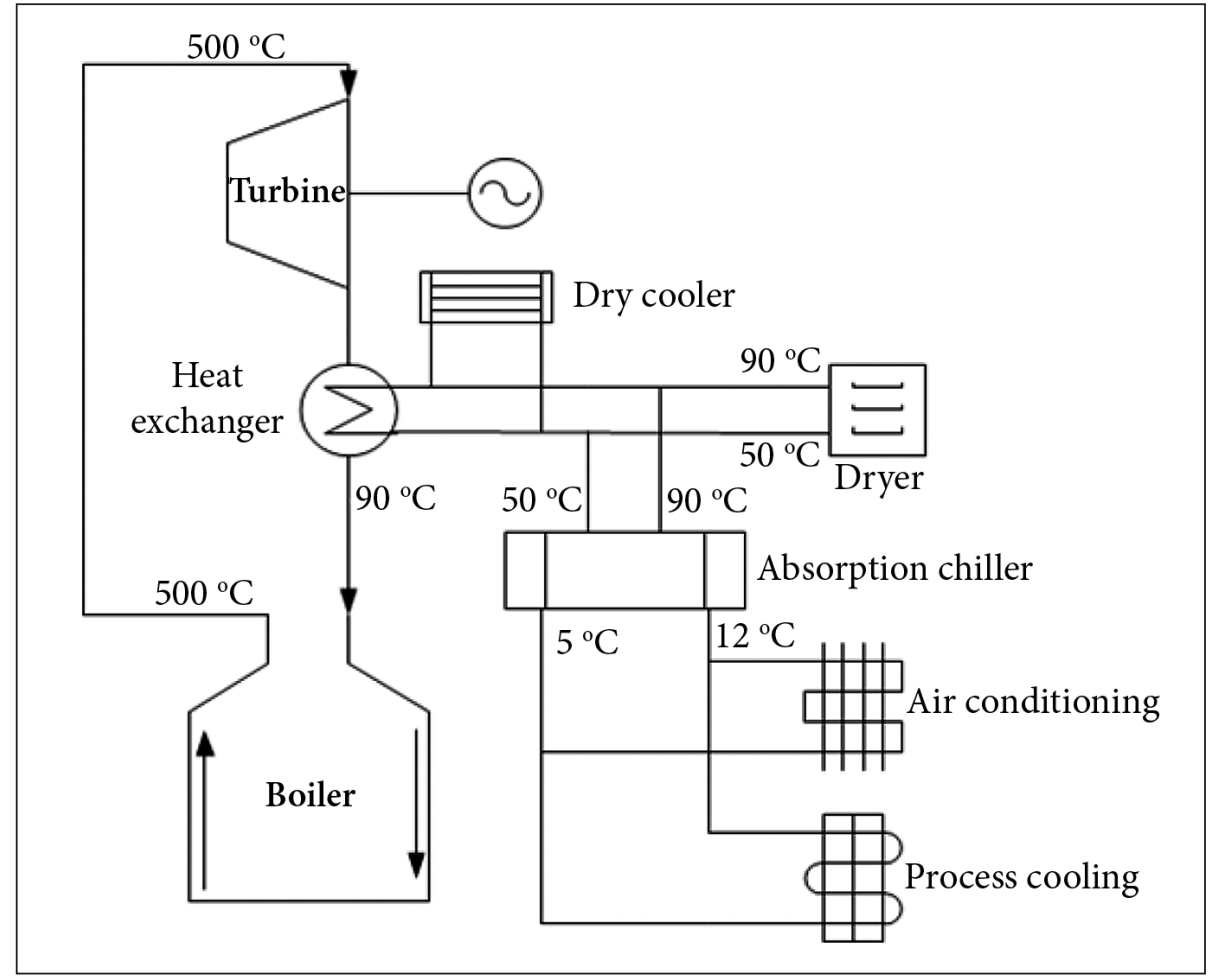

Fig. 3. Proposed technical solution for the Industrial CHP cooling system

it provides. The savings are counted as 0 , because due to the small scale cooling demand there is no size effect and the operation cost of the absorption chiller is as bg as the existing cooling equipment operation cost. If the existing cooling devices are replaced by the absorption chiller, then there will also be some electricity consumption involved - cold water pump, absorption chiller own consumption, etc. Therefore in this study the electricity consumption is neutral when making

Table 2. Case study industry calculation results

\begin{tabular}{|c|c|c|c|}
\hline Output data & Variable & Value & Unit \\
\hline Required process cooling & & 1346 & $\mathrm{MWh}_{\mathrm{th}}$ \\
\hline Process cooling load & $W_{P C}$ & 1583 & $\mathrm{MWh}_{\mathrm{th}}$ \\
\hline Air conditioners load & $W_{A C}$ & 2491 & $\mathrm{MWh}_{\mathrm{th}}$ \\
\hline Total cooling load & & 4074 & $\mathrm{MWh}_{\mathrm{th}}$ \\
\hline Heat demand for cooling & $W_{\mathrm{h}}^{\mathrm{c}}$ & 5432 & MWh \\
\hline Heat demand for drying & $W_{h}^{H}$ & 147507 & MWh \\
\hline Excess heat & & 6180 & MWh \\
\hline Excess heat peak & & 7.8 & $\mathrm{MW}_{\text {th }}$ \\
\hline Heat for cooling & & 2927 & MWh \\
\hline Cooling load peak & & 1.7 & $\mathrm{MW}_{\mathrm{th}}$ \\
\hline Additional condensation need & & 3254 & MWh \\
\hline Condensation peak & & 6.8 & $\mathrm{MW}_{\text {th }}$ \\
\hline Additional electricity production & & 1057 & $\mathrm{MWh}_{\mathrm{e}}$ \\
\hline Additional electricity income & & 105478 & $€$ \\
\hline Additional fuel consumption & & 4476 & MWh \\
\hline Additional fuel cost & & 53708 & $€$ \\
\hline Additional profit & & 51770 & $€$ \\
\hline Payback time & & 5.6 & Years \\
\hline
\end{tabular}


the transfer from the existing electricity driven cooling system to the absorption chiller based cooling. The main income in this study comes from the CHP increased electricity production.

For the purpose of the simplification of the calculations in this study the capital cost and the interest rates were not taken into account. If some additional field tests are done, then these can be taken into account in future studies. In case there will be some operational savings involved, then this makes the feasibility even better.

It should be noted that this study was performed by taking into account the existing subsidy mechanisms and therefore the results are dependent on the energy policy. In case the energy policy should change the results can differ as well. However, the developed method is still valid in any case even when there is no subsidy mechanism involved, because the equations can still be used for the feasibility study. The developed method is not dependent on the subsidy mechanism, but rather takes this into account, because it plays a key role in the case study calculations. However, the developed method can be used in any CHP system conversion calculations. This study focused only on the producer aspect and did not take into account the indirect influence for other market participants or wider aspects to the national energy mix.

\section{CONCLUSIONS AND FUTURE WORK}

The traditional CHP plant can be converted into a CCHP plant if sufficient cooling demand is available. This study developed a method to calculate and assess the effectiveness of the CHP conversion to a CCHP plant. An actual case study was performed on the existing wood industry facility which operates the on-site CHP plant. The case study facility actual data was modeled for the calculation purposes. The investment payback time for the absorption chiller based cooling technology was found to be less than 6 years. Using the absorption chiller enables a CHP plant to become a CCHP plant which also produces more electricity in the summer period due to the increased overall heat load. Additionally producing the cooling energy from excess heat means also savings in the environmental aspect through savings in primary fuels.
In the future the developed approach should be studied on similar industrial CHPs which have a constant cooling need and compared to the results found in this study. Furthermore, an actual practical case study conversion should be made in order to compare the practical results with the theoretical results found in this paper. The practical conversion tests would be especially necessary to compare the heat based cooling operational savings with the traditional cooling.

\section{ACKNOWLEDGEMENTS}

This research was supported by European Social Fund's Doctoral Studies and Internationalization Program DoRa, which is carried out by Foundation Archimedes, Program "Doctoral School of Energy and Geotechnology II" and the Estonian Ministry of Education and Research (Project SF0140016s11).

Received 31 January 2014 Accepted 5 May 2014

\section{References}

1. Canova A., Cavallero C., Freschi F., Giaccone L., Repetto M., Tartaglia M. Comparative Economical Analysis of a Small Scale Trigenerative Plant: A Case Study. Proceedings of the Industry Applications Conference 2007. 42nd IAS Annual Meeting. Conference Record of the 2007 IEEE. P. 1456-1459.

2. Fang F., Wang Q. H., Shi Y. A novel optimal operational strategy for the CCHP system based on two operating modes. IEEE Transactions on Power Systems. 2012. Vol. 27(2). P. 1032-1041.

3. Mago P. J., Chamra L. M. Analysis and optimization of CCHP systems based on energy, economical, and environmental considerations. Energy and Buildings. 2009. Vol. 41(10). P. 1099-1106.

4. Svensson I.-L., Moshfegh B. System analysis in a European perspective of new industrial cooling supply in a CHP system. Applied Energy. 2011. Vol. 88(12). P. 5164-5172.

5. Wang R. Z., Oliveira R. G. Adsorption refrigeration - An efficient way to make good use of waste heat and solar energy. Progress in En- 
ergy and Combustion Science. 2006. Vol. 32(4). P. 424-458.

6. Lira-Barragán L. F., Ponce-Ortega J. M., Serna-González M., El-Halwagi M. M. Synthesis of integrated absorption refrigeration systems involving economic and environmental objectives and quantifying social benefits. Applied Thermal Engineering. 2013. Vol. 52(2). P. 402419.

7. Teichmann D., Stark K., Müller K., Zöttl G., Wasserscheid P., Arlt W. Energy storage in residential and commercial buildings via Liquid Organic Hydrogen Carriers (LOHC). Energy and Environmental Science. 2012. Vol. 5(10). P. 90449054.

8. Chicco G., Mancarella P. From cogeneration to trigeneration: Profitable alternatives in a competitive market. IEEE Transactions on Energy Conversion. 2006. Vol. 21(1). P. 265-272.

9. Neally T., Boljevic S., Conlon M. F. Impact of Combined Heat and Power generation on an industrial site distribution network. Proceedings of 47th International Universities Power Engineering Conference, UPEC 2012. 2012. P. 1-7.

10. Trygg L., Amiri S. European perspective on absorption cooling in a combined heat and power system - A case study of energy utility and industries in Sweden. Applied Energy. 2007. Vol. 84(12). P. 1319-1337.

11. Difs K., Trygg L. Pricing district heating by marginal cost. Energy Policy. 2009. Vol. 37(2). P. 606-616.

12. Chandan V, Anh-Tuan D., Baoduo J., Jabbari F., Brouwer J., Akrotirianakis I., Chakraborty A., Alleyne A. Modeling and Optimization of a Combined Cooling, Heating and Power Plant System. Proceedings of the American Control Conference, ACC 2012. P. 3069-3074.

13. Petkajee T., Banjerdpongchai D. Multi-objective approach to economic and environmental optimal operations of cogeneration for building energy management system. Proceedings of 10th International Conference on Electrical Engineering / Electronics, Computer, Telecommunications and Information Technology, ECTI-CON 2013. P. 1-6.

14. Buckley L., Boljevic S., Barry N. Impact of combined heat and power (CHP) plant on small and medium size enterprise (SME), energy supply used as trigeneration. Proceedings of the Universities Power Engineering Conference, UPEC 2009. P. 1-5.

15. Chernyaev A., Makarchyan V., Andryushin A. Combined heat and power plants load distribution optimization. Proceedings of 45th International Power Engineering Conference, UPEC 2010. P. 1-4.

16. Wu J.-Y., Wang J.-L., Li S. Multi-objective optimal operation strategy study of micro-CCHP system. Energy. 2012. Vol. 48(1). P. 472-483.

17. Liu M., Shi Y., Fang F. A new operation strategy for CCHP systems with hybrid chillers. Applied Energy. 2012. Vol. 95. P. 164-173.

18. Maraver D., Sin A., Sebastián F., Royo J. Environmental assessment of CCHP (combined cooling heating and power) systems based on biomass combustion in comparison to conventional generation. Energy. 2013. Vol. 57. P. 17-23.

19. Maraver D., Sin A., Royo J., Sebastián F. Assessment of CCHP systems based on biomass combustion for small-scale applications through a review of the technology and analysis of energy efficiency parameters. Applied Energy. 2013. Vol. 102. P. 1303-1313.

20. Cho H., Mago P. M., Luck R., Chamra L. M. Evaluation of CCHP systems performance based on operational cost, primary energy consumption, and carbon dioxide emission by utilizing an optimal scheme. Applied Energy. 2009. Vol. 86. P. 2540-2549.

21. Latõšov E., Volkova A., Siirde A. The impact of subsidy mechanisms on biomass and oil shale based electricity cost prices. Oil Shale. 2011. Vol. 28(1). P. 140-151.

22. Valdma M., Tammoja H., Keel M. Soojuselektrijaamade talitluse optimeerimine. Tallinn: TUT Press, 2008. 37 p.

23. European Union Directive 2012/27/EU.http://eurlex.europa.eu/LexUriServ/LexUriServ.do?uri= OJ:L:2012:315:0001:0056:EN:PDF

24. Estonian Statistical Database. Annual Report for Wood Fuel Price 2012. http://pub.stat.ee/pxweb.2001/Database

25. Estonian State Forest Sales Statistics. Annual Report 2012. http://rmk.ee/sale-o/sale-of-t

26. Electricity Market Price History. Nord Pool Spot 2012. www.nordpoolspot.com/Market-data1 
27. The Parliament of Estonia Electricity Market Act 03.03.2011. https://www.riigiteataja.ee/akt/ 128062012025

Priit Uuemaa, Haralds Vigants, Dagnija Blumberga, Imre Drovtar

\section{PRAMONINIŲ TERMOFIKACINIŲ JĖGAINIŲ PERTEKLINĖS ŠILUMOS EFEKTYVUS PANAUDOJIMAS VÉSAI}

Santrauka

Straipsnyje pateikta, kaip šiltuoju metų laiku termofikacinès jègainès perteklinę šilumą galètų panaudoti pramoneje. Siekiant didinti termofikacinès jègainès elektros gamybą efektyvus šilumos gamybos kiekis turi didèti. Šio straipsnio tikslas - pateikti pramoninèms kombinuoto šilumos ciklo jègainèms pasiūlymus, kaip panaudoti perteklinę šilumą vietinei vèsai. Straipsnyje pateikiamas metodas ir būdas, leidžiantis ịvertinti pramoninès termofikacinès jègainès potencialą ir ekonominę naudą iš perteklinès šilumos gaminant vietinę vèsą.

Raktažodžiai: kombinuota vėsa, kombinuoto šilumos ciklo jègainè, energijos efektyvumas, termofikacinès jègainès, pramoniniai procesai

Приит Уэмаа, Гаральдс Вигантс, Дагния Блумберга, Имре Дровтар

\section{ЭФФЕКТИВНОЕ ИСПОЛЬЗОВАНИЕ ИЗБЫТКА ТЕПЛА ТЭЦ В ПРОМЫШЛЕННЫХ УСЛОВИЯХ ДЛЯ ОХЛАЖДЕНИЯ}

\section{Резюме}

Настоящее исследование рассматривает возможности утилизации избытка тепла теплоэлектроцентрали (ТЭЦ) в промышленности во время горячих периодов, когда потребности в тепле ограничены. Чтобы увеличить выработку электричества ТЭЦ, необходимо увеличить тепловую нагрузку. Задача настоящей статьи - предоставить решение по поводу утилизации избытка тепла ТЭЦ с целью локального охлаждения. Исследование разрабатывает метод и модель оценки потенциала и экономической выгоды объектов ТЭЦ для обеспечения локального охлаждения с помощью избытка тепла.
В зависимости от специализации промышленности, потребление тепла, обычно, ниже в летнее время, тогда как нагрузка по охлаждению более высокая в то же время. Следовательно, это и есть идеальная кривая потребления для утилизации избытка тепла. Максимальное производство тепла ограничено в летнее время из-за уменьшения потребности в тепле со стороны потребителей. Поскольку ТЭЦ промышленного масштаба, в основном, работают с турбинами противодавления, с целью увеличения эффективности, выработка электроэнергии увеличивается во время периодов уменьшения потребности в тепле. Следовательно, поиск решений по увеличению тепловой нагрузки является ключевым фактором для увеличения производства электричества ТЭЦ и, отсюда, экономических показателей завода.

Технически ТЭЦ может также работать в конденсационном режиме во время летнего периода, если завод имеет дополнительное охлаждающее оборудование в достаточном объеме. Однако, относительно низкий уровень электрического КПД и рыночной цены на электричество не покрывает текущих затрат на топливо. Используя избыток тепла при охлаждении для получения условий, благоприятных для технологического процесса позволяет возможность работы ТЭЦ в качестве базовой электростанции, которая производит электричество при полной нагрузке на протяжении всего года, увеличивая операционную прибыль. Главным образом, из-за увеличения производства электричества получается дополнительный доход. Какой-то доход также мог бы получаться от сбережений по затратам на охлаждение, которые, в противном случае, могли бы быть понесены в случае применения управляемых электричеством охладителей. Если ТЭЦ использует биотоплива, необходимо дополнительное финансирование в виде субсидий, которые предоставляют многие страны для эффективного производства возобновляемой электроэнергии.

Целью настоящего исследования является разработка рентабельности абсорбционной холодильной установки в лесной промышленности в условиях открытого рынка электричества. 
Настоящее исследование показало, что следует разрабатывать возможности охлаждения с помощью вырабатываемого тепла в отраслях промышленности, в которых задействованы рабочие ТЭЦ. Традиционные ТЭЦ можно конвертировать в комбинированные охлаждающие и тепловые электростанции (КОТЭ), если существует потребность в охлаждении на производстве. Абсорбционная холодильная установка используется для производства холодной воды из тепловой сети и, следовательно, переработки избытка тепла. В настоящем исследовании было показано, что срок окупаемости абсорбционной холодильной установки составляет менее 6 лет и, что это позволяет промышленной ТЭЦ непрерывно производить больше электричества в летнее время. Это, к тому же, означает, что уменьшается влияние на окружающую среду, с помощью уменьшения затрат на первичные топлива.

В будущем, следует изучить подобные промышленные ТЭЦ, у которых существует необходимость в постоянном охлаждении. Также, необходимо установить охлаждающий блок и сравнить результат его действия с теоретическими исследованиями. Практическое исследование преобразования будет необходимо для сравнения рабочего энергопотребления исследуемого случая и абсорбционного охлаждения.

Ключевые слова: смешанное охлаждение, теплоэлектроцентраль, энергетический КПД, системы тепло охлаждения, промышленные процессы 